\title{
ARTICLE
}

Acute lymphoblastic leukemia

\section{Bone marrow niche-derived extracellular matrix-degrading enzymes influence the progression of B-cell acute lymphoblastic leukemia}

\author{
Divij Verma $\mathbb{1}^{1} \cdot$ Costanza Zanetti $^{1}$ - Parimala Sonika Godavarthy ${ }^{1} \cdot$ Rahul Kumar $^{1}$ - Valentina R. Minciacchi ${ }^{1}$

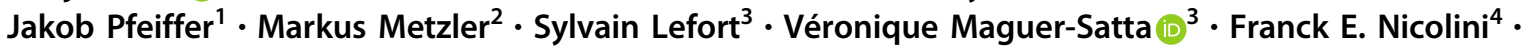 \\ Barbara Burroni $^{5} \cdot$ Michaela Fontenay $^{6}{ }^{6}$ - Daniela S. Krause (D) $^{1,7,8,9,10}$
}

Received: 11 June 2019 / Revised: 16 November 2019 / Accepted: 20 November 2019 / Published online: 9 January 2020

(c) The Author(s) 2019. This article is published with open access

\begin{abstract}
Specific and reciprocal interactions with the bone marrow microenvironment (BMM) govern the course of hematological malignancies. Matrix metalloproteinase-9 (MMP-9), secreted by leukemia cells, facilitates tumor progression via remodeling of the extracellular matrix (ECM) of the BMM. Hypothesizing that leukemias may instruct the BMM to degrade the ECM, we show, that MMP-9-deficiency in the BMM prolongs survival of mice with BCR-ABL1-induced B-cell acute lymphoblastic leukemia (B-ALL) compared with controls and reduces leukemia-initiating cells. MMP-9-deficiency in the BMM leads to reduced degradation of proteins of the ECM and reduced invasion of B-ALL. Using various in vivo and in vitro assays, as well as recipient mice deficient for the receptor for tumor necrosis factor (TNF) $\alpha$ (TNFR1) we demonstrate that B-ALL cells induce MMP-9-expression in mesenchymal stem cells (MSC) and possibly other cells of the BMM via a release of TNF $\alpha$. MMP-9-expression in MSC is mediated by activation of nuclear factor kappa B (NF- $\mathrm{B}$ ) downstream of TNFR1. Consistently, knockdown of TNF- $\alpha$ in B-ALL-initiating cells or pharmacological inhibition of MMP-9 led to significant prolongation of survival in mice with B-ALL. In summary, leukemia cell-derived Tnf $\alpha$ induced MMP-9-expression by the BMM promoting B-ALL progression. Inhibition of MMP-9 may act as an adjunct to existing therapies.
\end{abstract}

\section{Introduction}

Hematopoietic stem cells (HSC) reside in the bone marrow (BM) microenvironment (BMM) which is composed of

These authors contributed equally: Divij Verma, Costanza Zanetti, Parimala Sonika Godavarthy

Supplementary information The online version of this article (https:// doi.org/10.1038/s41375-019-0674-7) contains supplementary material, which is available to authorized users.

Daniela S. Krause

Krause@gsh.uni-frankfurt.de

1 Georg-Speyer-Haus, Institute for Tumor Biology and Experimental Therapy, 60596 Frankfurt am Main, Germany

2 Department of Pediatrics and Adolescent Medicine, University Hospital Erlangen, Erlangen, Germany

3 CRCL, Inserm U1052-CNRS UMR5286, Centre Léon Bérard, Lyon, France

4 Department of Hematology and INSERM U 1052, CRCL, Centre Léon Bérard, 69373 Lyon Cedex, France various cell types such as mesenchymal stem cells (MSC) and others, but also the extracellular matrix (ECM), cytokines, and other factors. Similarly, hematological malignancies are influenced by their BMM in their progression [1] and, conversely, they remodel the BMM suppressing normal hematopoiesis while supporting their own growth $[2,3]$. Remodeling of the BMM protects leukemia cells from chemotherapy- or tyrosine kinase inhibitor-induced cell death $[4,5]$ and inhibition of the remodeling process may increase sensitivity to chemotherapy $[5,6]$.

5 Pathology Department, Groupe Hospitalier Cochin, APHP, Paris Descartes University, Paris, France

6 Laboratory of Hematology Hôpital Cochin, Université Paris Descartes, 75014 Paris, France

7 Faculty of Medicine, Johann Wolfgang Goethe University, Frankfurt, Germany

8 Frankfurt Cancer Institute (FCI), Goethe University, Frankfurt am Main, Germany

9 German Cancer Consortium (DKTK), Heidelberg, Germany

10 German Cancer Research Center (DKFZ), Heidelberg, Germany 
The ECM of the BMM consists of collagens, proteoglycans, and glycoproteins and is involved in cell adhesion, binding of growth factors, and other functions [7]. ECM proteins such as tenascin-C [8], osteopontin [9], collagen IX $\alpha 1$ [10], or Del-1 [11] influence hematopoiesis, for instance via direct support of hematopoietic cell growth, regulation of apoptosis, alteration of the bone network, or promotion of HSC proliferation and differentiation, respectively. In leukemia, periostin promotes the growth of B-cell acute lymphoblastic leukemia (B-ALL) [12], while inhibition of osteopontin increases B-ALL burden [5].

BMM-derived proteases such as CD26 [13] or matrix metalloproteinases (MMP) play a role in HSC mobilization [14], while heparanase contributes to HSC retention [15]. Heparanase, cleaving heparan sulfate, and MMPs, which belong to the family of zinc-dependent endopeptidases, are involved in remodeling of the ECM. In cancer, MMPs may be produced by tumor [16] or stromal cells [17], where they degrade the ECM facilitating cancer progression. One such MMP is matrix metalloproteinase-9 (MMP-9) or gelatinase B [14], produced by macrophages, neutrophils [18], fibroblasts [19], MSC [20, 21], and other cells. Its expression may be increased in cancer cells of solid tumors, where it may correlate with metastasis [22], while in chronic lymphocytic leukemia (CLL) leukemia-cell specific, increased expression of MMP-9 contributes to disease progression [23]. Given the published data on tumor cell-specific secretion of MMP-9, we hypothesized that leukemia cells in B-ALL, the most common cancer in children, may remodel the BMM via the production of cytokines or other factors leading to increased expression of MMP-9 by cells of the BMM and, thereby, increased invasiveness of leukemia cells.

Indeed, in this report we show that tumor necrosis factor (Tnf) $\alpha$, secreted by B-ALL cells, leads to increased expression of MMP-9 in MSC via activation of the Tnf $\alpha$ receptor (TNFR)1-nuclear factor kappa-light-chainenhancer of activated B cells nuclear factor kappa B (NF$\kappa \mathrm{B})$ pathway and increased invasiveness of B-ALL cells. Our results further suggest that MMP-9 inhibition may represent a feasible adjunct treatment strategy in B-ALL, where leukemia relapse and progression remain major concerns.

\section{Materials and methods}

\section{Mice}

C57/BL6 and MMP-9 knockout (KO) mice (on a C57/BL6 background) were purchased from Charles River Laboratories (Sulzfeld, Germany). TNFR1-deficient mice were a kind gift from Prof. Florian Greten, Georg-Speyer-Haus.
Heparanase $\mathrm{KO}$ mice were obtained from the European Conditional Mouse Mutagenesis Program. All murine studies were approved by the local animal care committee (Regierungspräsidium Darmstadt).

\section{Statistical analysis}

Statistical significance between different treatment groups was assessed by Student's $t$ test using Prism Version 6 software (GraphPad, La Jolla, CA). When multiple hypotheses were tested, one-way ANOVA and a Tukey Test as post hoc test were used. Differences in survival were assessed by Kaplan-Meier nonparametric tests (Log-rank or Wilcoxon tests). Data were presented as mean \pm s.e.m, and differences were considered significant when $P$ values $\leq 0.05$.

\section{Results}

\section{Deficiency of MMP-9 in the BMM prolongs the survival of mice with B-ALL}

As a role of MMP-9 (and the ECM-degrading enzyme heparanase), derived from the BMM, had not previously been implicated in B-ALL, we transplanted wild type BM transduced with retrovirus expressing the oncogene $B C R-A B L 1$, which is associated with $3 \%$ of pediatric B-ALL and $25 \%$ of adult B-ALL, into heparanase- or MMP-9-deficient or control recipient mice. We observed no significant differences in ${\mathrm{BCR}-\mathrm{ABL} 1^{+}}^{+}\left(\mathrm{GFP}^{+}\right) \mathrm{BP}-1^{+}$pre-B cells in the peripheral blood (Fig. S1A and Table S1) or in the survival of heparanase-deficient compared with wild type recipient mice (Fig. S1B). In contrast, a significantly reduced BCR-ABL1 ${ }^{+}$ $\left(\mathrm{GFP}^{+}\right) \mathrm{BP}^{-1}{ }^{+}$leukemia load $(P=0.003$, Fig. 1a), as well as prolonged survival $(P=0.001$, Fig. 1b) was observed in MMP-9-deficient mice with B-ALL. In contrast, deficiency of MMP-9 in B-ALL-initiating cells did not alter survival in wild type recipient mice compared with controls (Fig. S1C). No major abnormalities were observed in peripheral blood, BM or spleen (Figs. S2A-E), and percentages of $\mathrm{Lin}^{-} \mathrm{c}-\mathrm{Kit}^{+} \mathrm{Sca}-$ $1^{+}$(LKS) and LKS CD150 ${ }^{+} \mathrm{CD}^{-} 8^{-}$(SLAM) cells (Fig. S2F) in $\mathrm{BM}$ or spleen and colony formation (Fig. S2G) did not differ between wild type and MMP-9 KO mice.

We transplanted total BM from wild type versus MMP-9deficient recipient mice with established B-ALL into wild type secondary recipient mice to assess the self-renewal capacity of leukemia-initiating cells (LIC). This revealed a significant reduction of leukemia load ( $P=0.05$, Fig. 1c), as well as significant prolongation of survival of secondary recipients transplanted with $\mathrm{BM}$ from MMP-9-deficient mice with B-ALL $(P=0.01$, Fig. 1d). In summary, these results suggest that BMM-derived MMP-9 contributes to B-ALL progression, at least partly by reduction of LIC. 

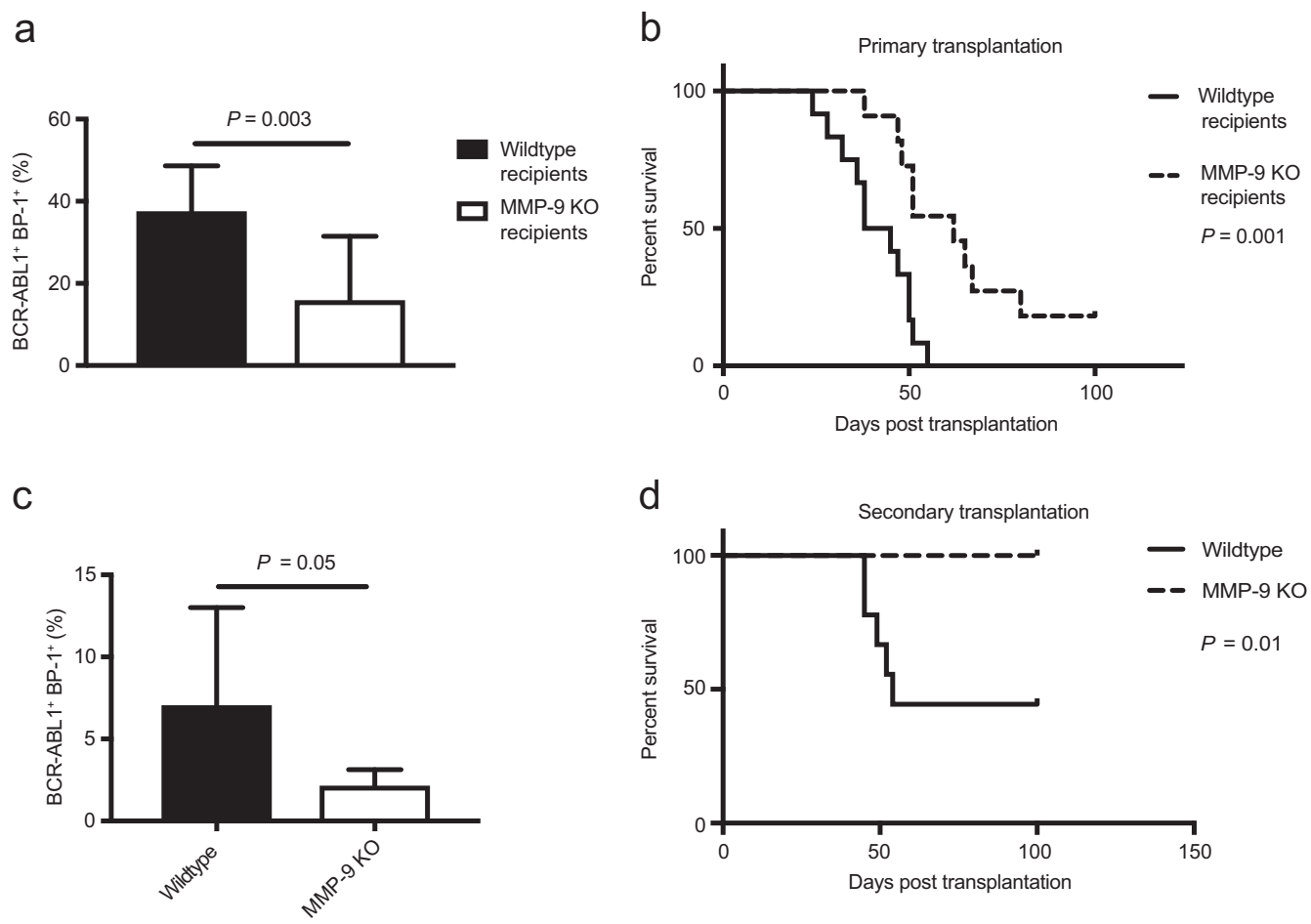

Fig. 1 Deficiency of MMP-9 in the BMM prolongs survival of mice with B-ALL. a Percentage of $\mathrm{GFP}^{+}\left(\mathrm{BCR}-\mathrm{ABL1} 1^{+}\right) \mathrm{BP}^{-1}{ }^{+}$cells in peripheral blood of wild type (black) or MMP-9 KO (white) recipient mice on day 25 of transplantation of $\mathrm{BCR}-\mathrm{ABL1}{ }^{+}$transduced bone marrow in the B-ALL model $(P=0.003 ; t$ test, $n=10)$. b Kaplan-Meier-style survival curve of wild type (solid line) or MMP-9 $\mathrm{KO}$ (dashed line) recipient mice transplanted with $1 \times 10^{6}$ BCR-ABL1transduced donor bone marrow cells $(P=0.001$, Log-rank test, $n=12)$.

\section{MMP-9-deficiency in the BMM does not alter the homing capacity, cell cycle, or apoptosis of BCR- $\mathrm{ABL1}^{+}$B-ALL cells}

Testing the reason for prolonged survival of MMP-9deficient mice with B-ALL, we did not observe any significant differences in the homing efficiency of $\mathrm{GFP}^{+}$ $\left(\mathrm{BCR}-\mathrm{ABL} 1^{+}\right) \mathrm{BP}^{-} 1^{+} \mathrm{LIC}$, which represent the LIC in this model (DSK, unpublished data), to a wild type or MMP-9-deficient BMM (Fig. S3A). Analysis of cell cycle (Fig. S3B) or apoptosis (Fig. S3C) of B-ALL cells from an MMP-9-deficient versus a wild type BMM did not reveal significant differences, suggesting that the observed differences in survival of wild type versus MMP-9 KO mice were not due to alterations in homing, cell cycle, or apoptosis of leukemia cells [1].

\section{MMP-9 deficiency leads to higher levels of extracellular matrix proteins in the BMM}

To investigate the impact of MMP-9-deficiency on levels of ECM proteins in the BMM, we performed c Percentage of $\mathrm{GFP}^{+}\left(\mathrm{BCR}-\mathrm{ABL} 1^{+}\right) \mathrm{BP}-1^{+}$cells in peripheral blood of wild type secondary recipients of $\mathrm{BCR}-\mathrm{ABL1}^{+}$bone marrow transplanted from wild type (black) or MMP-9 KO (white) primary mice with established B-ALL on day 18 after transplantation $(P=0.05 ; t$ test, $n=8)$. d Kaplan-Meier-style survival curve of wild type secondary recipients of unsorted $\mathrm{BCR}-\mathrm{ABL1}{ }^{+}$bone marrow from wild type (solid line) or MMP-9 KO (dashed line) primary mice with established B-ALL $(P=0.01$, Log-rank test, $n=9)$.

immunoblotting of total protein lysates from crushed bones of wild type versus MMP-9-deficient mice probing with an antibody to fibronectin, a substrate of MMP-9. This $(P=0.006$, Fig. 2a, b) and immunofluorescence staining $(P=0.021$, Figs. $2 \mathrm{c}$ and $\mathrm{S} 4 \mathrm{~A})$ revealed increased levels of fibronectin in the samples derived from MMP-9deficient mice. Consistently, another ECM protein, laminin, $(P=0.02$, Figs. $2 \mathrm{~d}$ and $\mathrm{S} 4 \mathrm{~B})$ was also increased in bone sections of MMP-9-deficient compared to wild type mice. As laminin is also expressed by endothelial basement membranes [24], we evaluated $\mathrm{CD}^{+} 1^{+}$endothelial cells and observed a significant reduction of $\mathrm{CD} 31^{+}$cells in the BM of MMP-9 KO compared with wild type mice $(P<0.0001$, Fig. S4C-D). We confirmed increased levels of fibronectin $(P=0.002$, Figs. 2e and S4E), laminin ( $P=0.043$, Figs. 2e and S4F) and collagen $(P=0.061$, Figs. 2e and S4G) in MMP-9-deficient compared with wild type mice with B-ALL (Fig. 2e). These data suggest that MMP-9-deficiency in the BMM increases the levels or decreases the degradation of ECM proteins in homeostatic conditions, as well as in leukemia. 

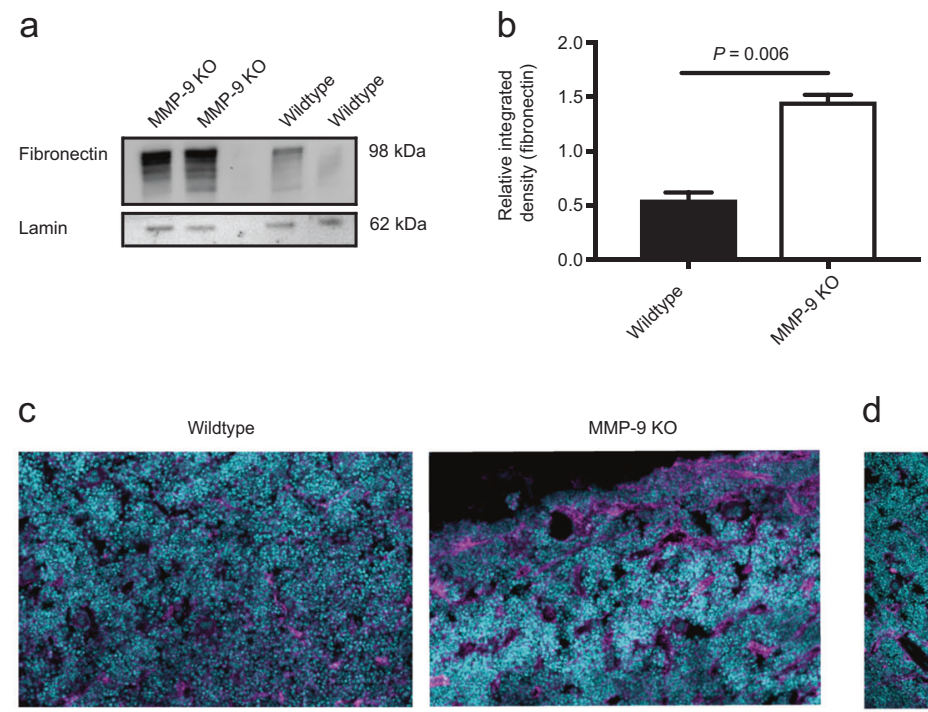

d

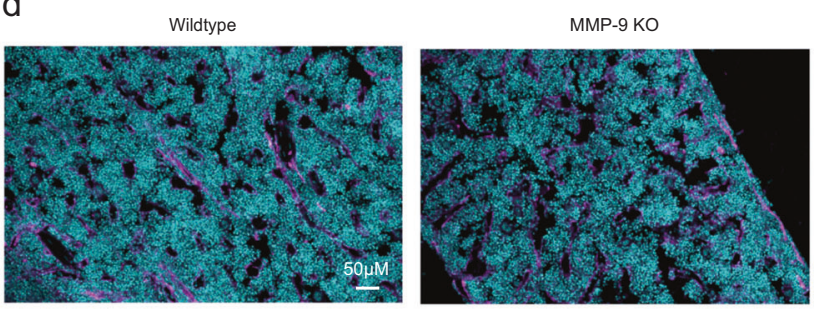

Fibronectin

Laminin
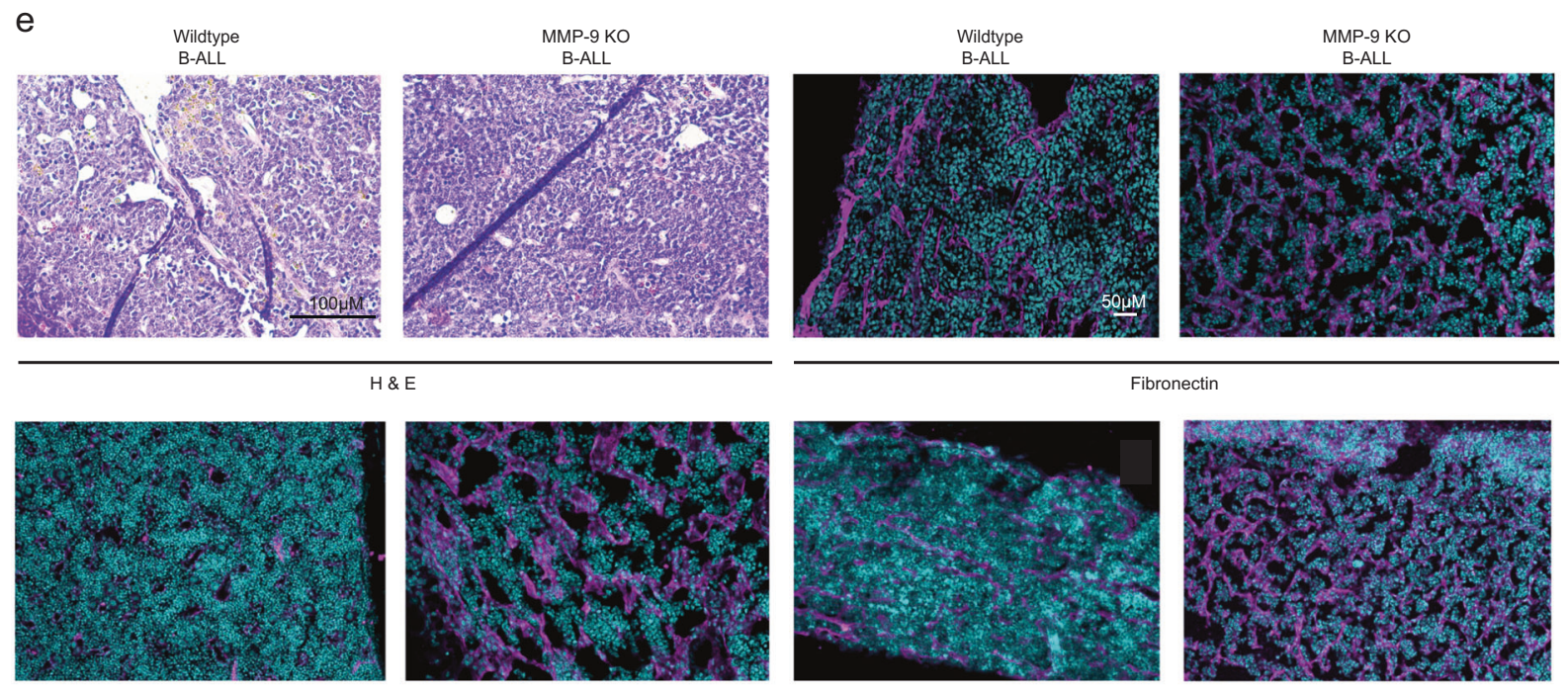

Laminin

Collagen

Fig. 2 MMP-9 KO mice are characterized by an increased amount of extracellular matrix proteins in the BMM. Immunoblot (a) and integrated density of the highest molecular weight fibronectin band (b) from a showing fibronectin bands of varying molecular weights in protein lysates from crushed bones of wild type versus MMP-9 KO mice. The bone marrow was flushed before crushing the bones $(P=$ $0.006 ; t$ test). The immunoblot is representative of three independent experiments. c, $\mathbf{d}$ Representative immunofluorescence images of bone sections of wild type or MMP-9 KO mice stained with antibodies to

\section{MMP-9 promotes the invasion of B-ALL cells}

We hypothesized that BMM-derived MMP-9 also has a role in promoting the invasion of B-ALL cells. Indeed, the preosteoblastic cell line MC3T3, MSC, macrophages from the BMM, and-to a much lesser extent - the endothelial cell line H5V expressed MMP-9 (Fig. S4H). Further, the percentage of $\mathrm{BCR}-\mathrm{ABL} 1^{+}\left(\mathrm{GFP}^{+}\right) \mathrm{BP}^{+}{ }^{+}$cells in $\mathrm{BM}$ fibronectin (pink; c) or laminin (pink; d). The scale bar depicts $50 \mu \mathrm{M}$. $n=3-4$. e Bone sections of wild type or MMP-9 KO mice transplanted with BCR-ABL1- transduced bone marrow in the B-ALL model stained with hematoxylin and eosin (H\&E) (top left) or antibodies to fibronectin (top right), laminin (bottom left) or collagen (bottom right) in immunofluorescence studies. The scale bar depicts $100 \mu \mathrm{M}$ in the H\&E-stained slides and $50 \mu \mathrm{M}$ in the immunofluorescence studies.

( $P=0.05$, Fig. 3a) was reduced, which is likely causative of the survival prolongation in secondary recipient mice transplanted with BM from MMP-9-deficient mice with BALL (Fig. 1d). BCR-ABL1 ${ }^{+}\left(\mathrm{GFP}^{+}\right) \mathrm{BP}^{+}{ }^{+}$cells were also reduced in lung $(P=0.05$, Fig. $3 \mathrm{~b})$, spleen $(P=0.02$, Fig. 3c), liver $(P=0.03$, Fig. $3 \mathrm{~d})$, and meninges $(P=0.02$, Figs. 3e, f and S4I) of MMP-9-deficient compared with wild type mice with B-ALL. 

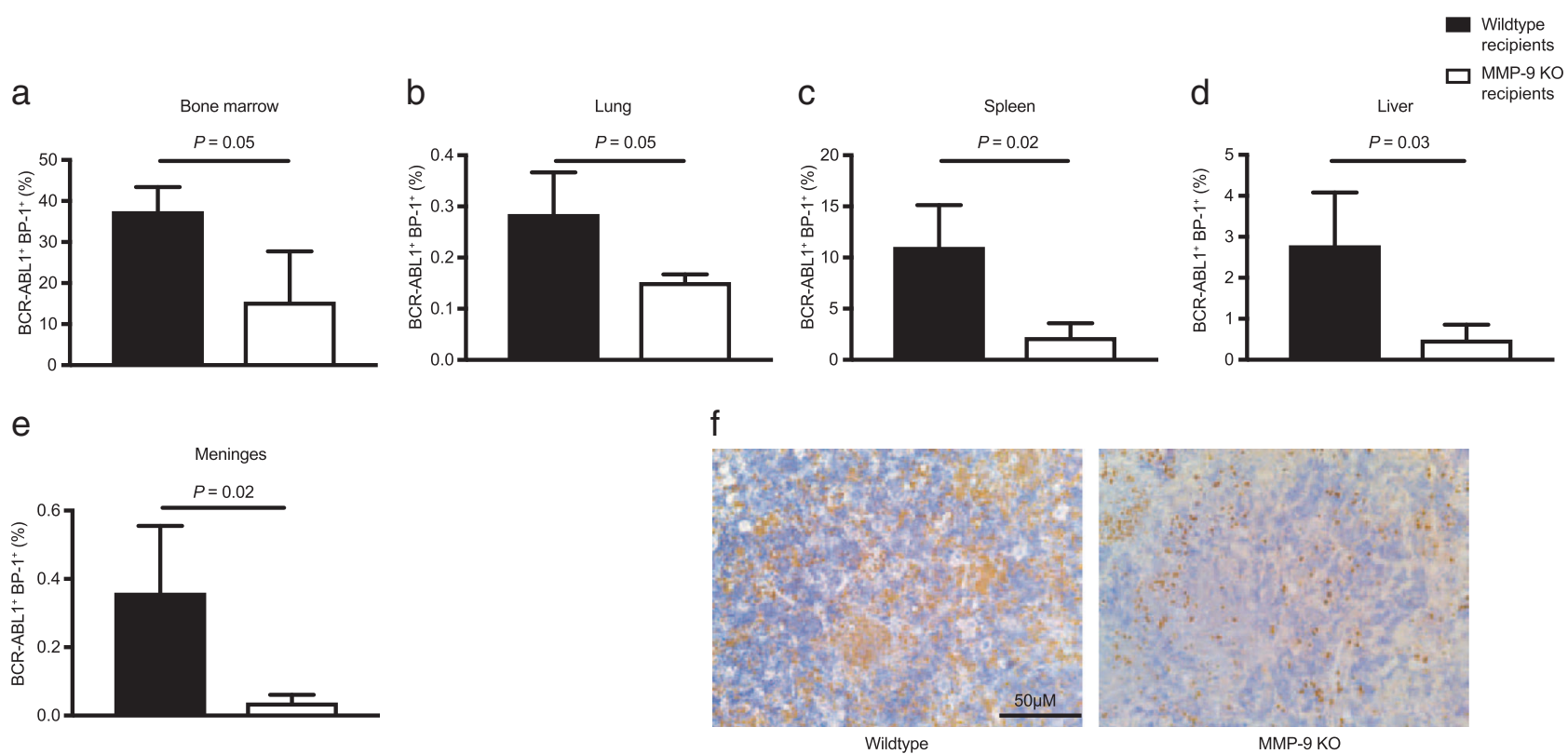

9

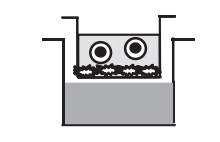

BCR-ABL1+B220* B-ALL cells Wildtype / MMP-9 KO MSC

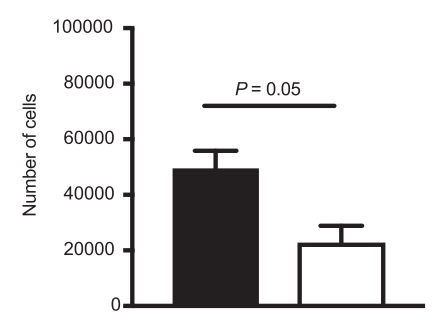

Fig. 3 MMP-9-deficieny in recipients of B-ALL-initiating cells leads to reduced infiltration of organs. (a-e) Percentage of $\mathrm{GFP}^{+}$ $\left(\mathrm{BCR}-\mathrm{ABL} 1^{+}\right) \mathrm{BP}^{-} 1^{+}$cells in bone marrow (a), lung (b), spleen (c), liver (d), and meninges (e) of wild type (black) or MMP-9 KO (white) mice transplanted with BCR-ABL1-transduced bone marrow on day 20 after transplantation ( $n=4, t$ test, $P$ values as indicated). $\mathbf{f}$ Representative immunohistochemistry images of $\mathrm{GFP}^{+}\left(\mathrm{BCR}-\mathrm{ABL} 1^{+}\right)$cells (detected by immunoperoxidase using yellow-brown horseradish-peroxidase chromogen) in the meninges of wild type (left) or MMP-9 KO (right)

Macrophages and neutrophils from the BMM were unlikely to be contributing to MMP-9-production [18], as they were reduced to $\sim 5 \%$ of total BM cells in wild type mice with B-ALL (Fig. S4J). They were largely negative for GFP (BCR-ABL1) and, therefore, MMP-9 deficient in MMP-9 KO mice (Fig. S4K). In an in vitro transwell-based invasion assay we revealed reduced migration of B-ALL cells, if they had been cocultured on MMP-9-deficient compared with wild type MSC, to the chemoattractant stromal-derived factor (SDF)- $1 \alpha(P=0.05$, Figs. $3 g$ and S5A-B $)$ or the B-cell chemoattractant $\mathrm{C}-\mathrm{X}-\mathrm{C}$ motif chemokine ligand 13 (CXCL13) $(P=0.013$, Fig. S6A), for which B-ALL cells express the corresponding $\mathrm{C}-\mathrm{X}-\mathrm{C}$ motif chemokine receptor 5 (CXCR5) (Fig. S6B). In contrast, migration of B-ALL cells through a layer of $\mathrm{CD}_{11 \mathrm{~b}^{+} \mathrm{F} 4 / 80^{+}}$wild type or MMP-9deficient macrophages [25], known to be producers of MMP9 [18] and potential contaminants in stromal cultures [26], did mice transplanted with BCR-ABL1-transduced bone marrow on day 20 after transplantation. The scale bar depicts $50 \mu \mathrm{M} . n=4$. g Number of primary sorted murine $\mathrm{BCR}-\mathrm{ABL} 1^{+} \mathrm{BP}-1^{+} \mathrm{B}-\mathrm{ALL}$ cells which migrated from the upper chamber through a layer of wild type (black) or MMP-9 $\mathrm{KO}$ (white) mesenchymal stromal cells (MSC) to the lower chamber in a transwell/invasion assay containing $0.5 \mathrm{ng} / \mathrm{ml}$ SDF-1 $(P=0.05 ; t$ test, $n=2) .10^{5}$ leukemia cells had been plated and were allowed to migrate for $48 \mathrm{~h}$.

not differ significantly (Fig. S6C-D). In summary, BMMderived MMP-9 promotes the migration or invasion of $\mathrm{B}$ ALL cells into different peripheral organs, possibly via degradation of the ECM.

\section{B-ALL cells instruct the BMM to produce MMP-9 via the release of tumor necrosis factor $a$}

We hypothesized that B-ALL cells induce the expression of Mmp9 in the BMM. When we cocultured wild type MSC with normal BP-1-enriched B cells versus B-ALL cells, we observed increased expression of $M m p 9$ by MSC after coculture with B-ALL, but not normal B cells $(P=0.04$, Fig. 4a). A focused gene expression analysis of B-ALL cells revealed an $\sim 15$-fold increased expression of the proinflammatory cytokine $T n f \alpha$ in BaF3 cells transduced with BCR-ABL1 compared with empty vector $(P<0.001$, 
a
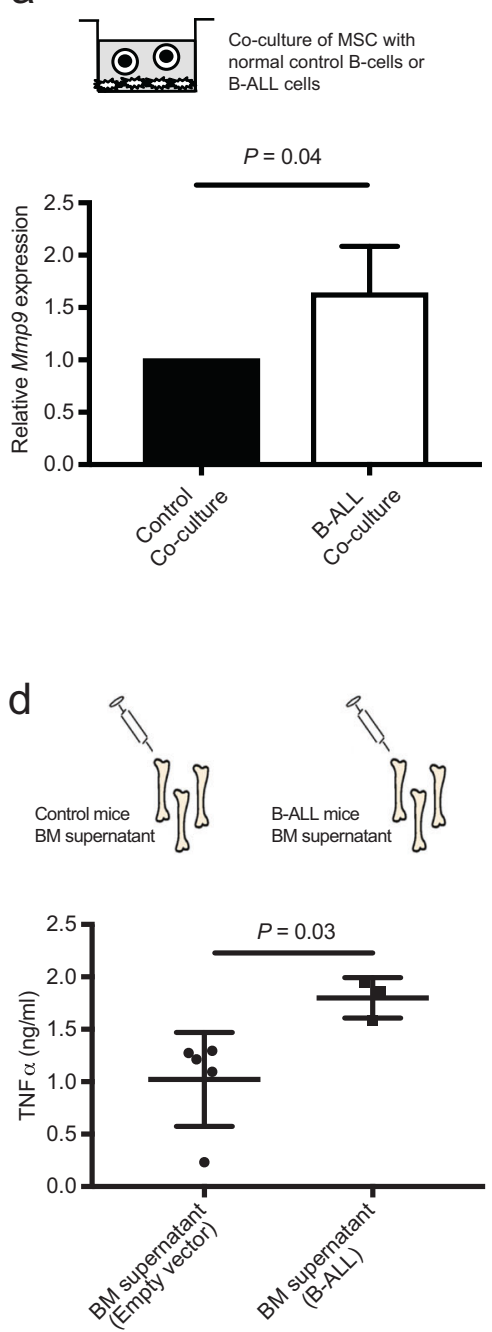

Fig. 4 B-ALL-derived Tnfo remodels the bone marrow microenvironment. a Relative expression of $M m p 9$ in wild type mesenchymal stromal cells after $48 \mathrm{~h}$ of coculture with $10^{5}$ normal B cells (black), which had been enriched by anti-BP-1 magnetically labeled antibodies, or whole bone marrow from mice with fully established B-ALL $\left(>95 \% \mathrm{BP}-1^{+} \mathrm{GFP}^{+}\left(\mathrm{BCR}-\mathrm{ABL}^{+}\right)\right.$cells in the bone marrow) (white). ( $P=0.04 ; t$ test, $n=4-6)$. b Relative expression of Vegfa, Tnf, IL6, IL1B, and IL1A in BaF3 cells transduced with empty vector (black)- or BCR-ABL1 (white)-expressing retrovirus ( $P$ values as indicated; $t$ test, $n=3-5$ ). c Concentration of $T n f \alpha$ in $\mathrm{ng} / \mathrm{ml}$ in the CM from cultured bone marrow cells from nonirradiated normal mice (black circles) or mice with B-ALL (black squares). The CM was harvested after 7 days of culture, and Tnf $\alpha$ was detected by ELISA $(P=0.002 ; t$ test, $n=4)$. d Concentration of $T n f \alpha$ in the bone marrow

Fig. 4b). More myeloid-associated cytokines were decreased in the BM of mice with B-ALL (Fig. S6E). Consistently, protein levels of $\operatorname{Tn} f \alpha$ in the conditioned medium (CM) harvested from cultured, primary BCR$\mathrm{ABL}^{+} \mathrm{B}-\mathrm{ALL}$ cells was significantly higher than in $\mathrm{CM}$ from healthy $\mathrm{BM}$ cells $(P=0.002$, Fig. 4c). Tnf $\alpha$ levels were also higher in the BM supernatant of mice which had received $\mathrm{BM}$ transduced with $\mathrm{BCR}-\mathrm{ABL} 1$ compared to supernatant, harvested by flushing bones with $100 \mu$ of PBS from wild type mice transplanted with empty vector (black circles)- or BCRABL1 (black squares)-transduced bone marrow $(P=0.03 ; t$ test, $n=$ 4-5). Tnf $\alpha$ was detected by ELISA. e Relative expression of Mmp9 in MSC after no treatment (black) or after in vitro treatment with $15 \mathrm{ng} / \mathrm{ml} \mathrm{Tnf \alpha}$ for 6 (lighter gray) or $24 \mathrm{~h}$ (darker gray) $(P<0.0001$; ANOVA, Tukey Test, $n=4-5$ ). f Absorbance (at $365 \mathrm{~nm}$ ) of fluorescent, emitted light after cleavage of an MMP-9-specific fluorogenic substrate, which had been incubated with the conditioned medium from MSC, that were untreated or treated with $15 \mathrm{ng} / \mathrm{ml} T n f \alpha(P<$ $0.0001 ; t$ test, $n=4-5$ ). The conditioned medium had been harvested $48 \mathrm{~h}$ after initiating Tnfo treatment, and the substrate had been incubated with the conditioned medium for 40-60 min.

empty vector $(P=0.03$, Fig. $4 d)$. Next, we investigated if increased secretion of Tnf $\alpha$ by BCR-ABL1 ${ }^{+}$cells may be responsible for inducing the expression of $M m p 9$ in the BMM. Indeed, in vitro treatment of MSC and MC3T3 cells with recombinant $T n f \alpha$ led to increased expression of $M m p 9$ in MSC $(P<0.0001$, Fig. 4e) and MC3T3 $(P=0.002$, Fig. S6F). To test if increased expression of Mmp9 in MSC after $\operatorname{Tn} f \alpha$ treatment leads to secretion of active, functional 
MMP-9 protein, we performed a fluorogenic in vitro assay, in which MMP-9-dependent hydrolysis of a fluorochromecoupled MMP-9-specific substrate liberates a fluorescent cleavage product. Hereby, we observed increased MMP-9 activity in the CM harvested from MSC $(P<0.001$, Fig. 4f) or MC3T3 $(P=0.04$, Fig. S6G) cells after treatment with Tnf $\alpha$. In order to test the specific proteolytic activity of MMP-9 and MMP-2, which is predominantly produced by mesenchymal cells [27], we performed gelatin zymographies. This revealed an increase of MMP-9 activity in the CM from MSC, but not macrophages, after exposure to Tnf $\alpha$ (Fig. S7A), regardless of whether the MSC had been depleted of macrophages (Fig. S7B-C). Similar findings were observed using lysates from MSC (Fig. S7D). An increase of MMP-9 activity was also found in H5V and MC3T3 cells after treatment with Tnf $\alpha$ (Fig. S7E). MMP-2 levels remained unaltered (Figs. S7A and C-E). In an effort to exclude the possibility that macrophages or neutrophils may be contributing to MMP-9 production, we demonstrated that lysates of whole BM fluids from wild type and, more prominently, MMP-9 KO mice transplanted with BCR-ABL1-transduced BM had lower MMP-9 activity than mice transplanted with empty vector control $^{+} \mathrm{BM}$ (Fig. S7F). Consistently, only the exposure of MSC, but not macrophages or neutrophils, to Tnfo led to increased MMP9 activity, as performed in serum-free conditions to abolish the contribution of MMP-9 or MMP-2 in serum (Fig. S7G). In addition, the $\mathrm{CM}$ and lysates of normal $\mathrm{B} 220^{+} \mathrm{B}$ cells revealed more MMP-9 activity than BCR-ABL1 ${ }^{+} \mathrm{B} 220^{+} \mathrm{B}$ cells (Fig. S7H). These data suggest that B-ALL cells produce Tnf $\alpha$ (and low amounts of MMP-9), which contributes to remodeling of the BMM leading to the release of functional MMP-9, predominantly by MSC.

\section{B-ALL cell-derived Tnfa activates the $T n f$ receptor 1- dependent NF-KB pathway inducing Mmp9 expression in BM niche cells}

Tnf $\alpha$ binds to its receptors, $\operatorname{Tnf}$ receptor (TNFR) 1 or TNFR 2, expressed on MSC. As TNFR1 has, generally, been implicated in proinflammatory conditions [28], we isolated MSC from TNFR1-deficient mice and treated them with Tnfo in vitro. This did not lead to increased expression of Mmp9 in TNFR1 deficient MSC (Fig. S8A) compared with untreated controls or compared with wild type MSC treated with Tnf $\alpha$ (Fig. 4e). The presence of TNFR1 deficient MSC in the transwell-invasion assay also led to a reduction of the invasive ability of B-ALL cells $(P=0.008$, Fig. 5a), suggesting that Tnf $\alpha$ signals to MSC via TNFR1. We stained MSC for components of the nuclear factor kappa-lightchain-enhancer of activated B cells (NF- $\mathrm{kB}$ ) protein complex, which had previously been implicated in Tnfomediated signaling $[29,30]$, to test its possible role for inducing $M m p 9$ expression. Indeed, we observed increased nuclear translocation and staining for phospho P65 (RelA), a transcription factor and activating partner in the NF- $\mathrm{KB}$ complex, in MSC treated with Tnfo compared with vehicle $(P=0.017$, Figs. 5b and S8B). To test, if NF- $\mathrm{kB}$ was directly inducing the expression of Mmp9 in MSC via binding to the MMP-9 promoter, we performed chromatin immunoprecipitation (CHIP) with an antibody to P65 on lysates from MSC treated with vehicle or Tnfo. This revealed that treatment with $T n f \alpha$ significantly increased the binding of P65 to the $M m p 9$ promoter $(P=0.05$, Fig. $5 \mathrm{c}$ ), but binding to a control region (located on chromosome 18) was undetectable.

Transplantation of BM cotransduced with BCR-ABL1expressing retrovirus and scrambled- versus Tnf-shRNAexpressing lentivirus led to a significant prolongation of survival of wild type recipient mice transplanted with Tnfo shRNA- compared with scrambled shRNA-expressing BCR-ABL1 ${ }^{+}$LIC $(P=0.03$, Figs. 5d and S8C). Consistently, culturing of MSC, macrophages, or neutrophils in the CM of BCR-ABL1 ${ }^{+}$BaF3 cells transduced with Tnfo shRNA-expressing lentivirus (Fig. S8D) led to a reduction of MMP-9 levels compared with cells cultured in the CM from scrambled shRNA $^{+}$BCR-ABL1 $^{+} \mathrm{BaF}$ cells (Fig. S8E). Taken together our data suggest that Tnfo, derived from B-ALL cells and contributing to B-ALL progression, binds to its receptor TNFR1 activating the NF$\kappa \mathrm{B}$ protein complex. $\mathrm{P} 65$ as a component of the activated NF- $\mathrm{KB}$ complex binds to the promoter of $\mathrm{Mmp} 9$, inducing its expression.

\section{Pharmacological inhibition of MMP-9 significantly prolongs survival of mice with B-ALL}

Next, we evaluated if inhibition of MMP-9 may be exploited therapeutically for the treatment of B-ALL. Inhibition of MMP-9 with a pharmacological inhibitor significantly reduced the percentage of $\mathrm{BCR}-\mathrm{ABL}^{+}$ $\left(\mathrm{GFP}^{+}\right) \mathrm{BP}^{+}{ }^{+}$cells in peripheral blood compared with vehicle-treated mice $(P=0.04$, Fig. 6a), and significantly prolonged survival ( $P=0.01$, Fig. $6 \mathrm{~b})$. To confirm that the survival prolongation of mice with B-ALL treated with an MMP-9 inhibitor was indeed due to reduced degradation of the ECM in the BMM, we performed immunofluorescence staining of bone sections. We observed reduced leukemic infiltration (Fig. 6c) and significantly increased levels of fibronectin $(P=0.001$, Figs. $6 \mathrm{c}$ and S9A), collagen $(P=$ 0.05 , Figs. $6 \mathrm{c}$ and S9B), and laminin $(P=0.002$, Figs. $6 \mathrm{c}$ and S9C) in the BMM of mice with B-ALL after treatment with an MMP-9 inhibitor compared with vehicle. We performed a secondary transplantation and observed a significant reduction of leukemia load in the peripheral blood of secondary recipient mice transplanted with $\mathrm{BM}$ from 


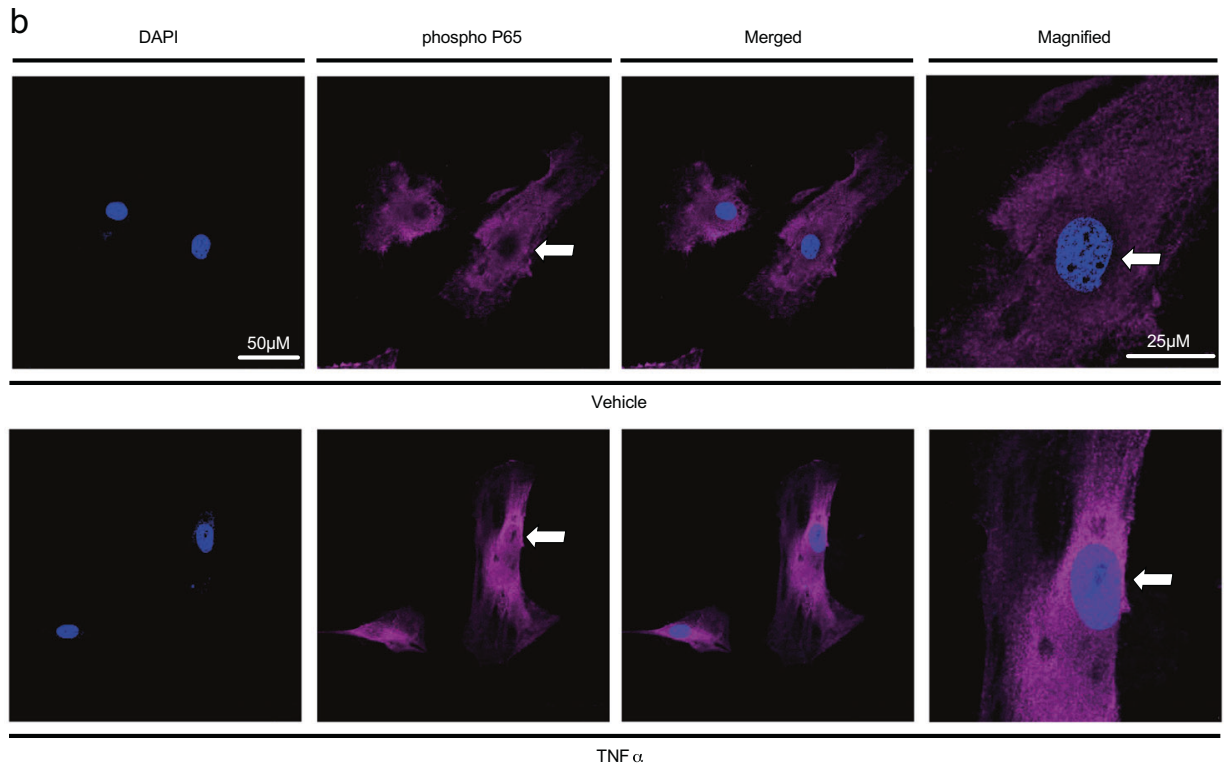

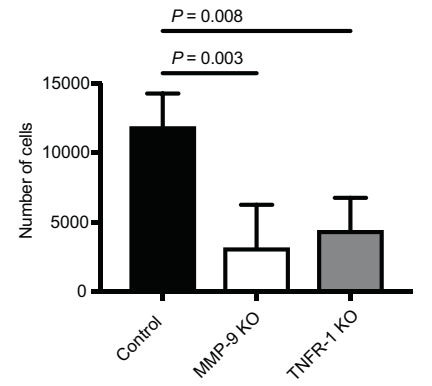

C

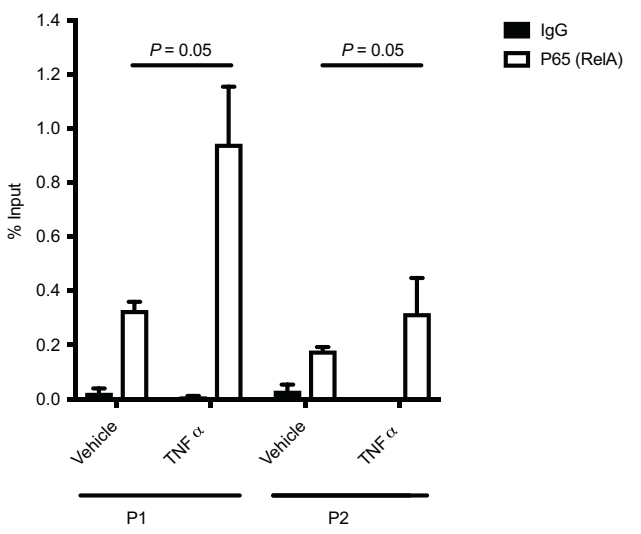

Fig. 5 Deficiency of $T$ f $f \alpha$ in B-ALL cells prolongs survival. a Number of primary murine BCR-ABL1 ${ }^{+} \mathrm{BP}-1^{+} \mathrm{B}-\mathrm{ALL}$ cells which migrated from the upper chamber through a layer of wild type (black), MMP-9 KO (white), or tumor necrosis factor receptor (TNFR)-1 KO (gray) MSC to the lower chamber in a transwell-invasion assay, which contained $500 \mathrm{ng} / \mathrm{ml} \mathrm{CXCL13} \mathrm{(} P$ value as indicated; ANOVA, Tukey test, $n=4-6) .10^{5}$ leukemia cells had been plated and were allowed to migrate for $24 \mathrm{~h}$. b Representative immunofluorescence images of MSC after $8 \mathrm{~h}$ of treatment with vehicle (top) or Tnf $\alpha$ (bottom), stained with an antibody to phospho P65 (red) and DAPI (blue). The scale bar

MMP-9 inhibitor-treated primary B-ALL mice compared with controls $(P=0.03$, Fig. $6 \mathrm{~d})$. However, disease induction in secondary recipients was inefficient, as can be observed in this B-ALL model (DSK, unpublished data), and no mice succumbed to B-ALL. In vitro plating of BALL cells from vehicle- versus MMP-9-inhibitor-treated mice on wild type MSC in limiting dilution to test proliferation of B-ALL cells demonstrated reduced cell proliferation if the cells were derived from an MMP-9 inhibitor-derived BMM $(P=0.009, \quad$ Fig. S9D $)$. d

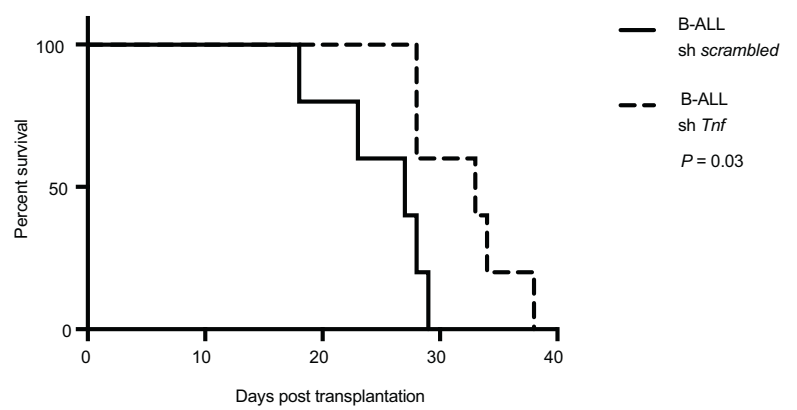

depicts $50 \mu \mathrm{m}$ in all images and $25 \mu \mathrm{m}$ in the magnified images (extreme right panel). $n=9-10$. The images are representative of two independent experiments. c Binding of P65 to the Mmp9 promoter in MSC treated with vehicle or $15 \mathrm{ng} / \mathrm{ml} T n f \alpha$ for $6 \mathrm{~h}$, as measured by a ChIP assay using an anti-P65 (white) or a control IgG (black) antibody and two different primer pairs (P1 and $\mathrm{P} 2)$ for $M m p 9(P=0.05, t$ test, $n=3$ ). d Kaplan-Meier-style survival curve for wild type C57/B16 recipients of BCR-ABL1-transduced bone marrow cotransduced with scrambled shRNA- (solid line) or Tnf $\alpha$ shRNA-expressing lentivirus (dashed line) in the B-ALL model $(P=0.03$, Log-rank test, $n=5)$.

Hypothesizing that MMP-9 inhibition in conjunction with standard chemotherapy with cytarabine (ara-C) may reduce the tumor load more efficiently than ara-C alone, we revealed a trend toward a reduced tumor burden by the MMP-9 inhibitor alone and a significant reduction of the tumor burden by ara- $\mathrm{C}$ alone or ara- $\mathrm{C}$ in combination with the MMP-9 inhibitor in peripheral blood (Fig. S10A), BM (Fig. S10B), and spleen (Fig. S10C), but not in lung (Fig. S10D). Spleen weights were significantly reduced in mice treated with ara-C or ara-C and the MMP-9 inhibitor 
a

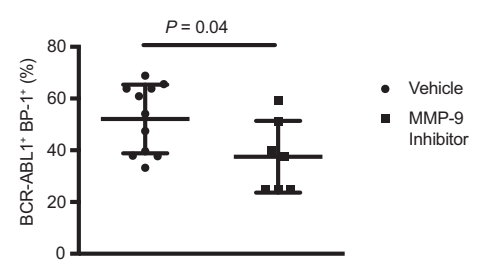

b

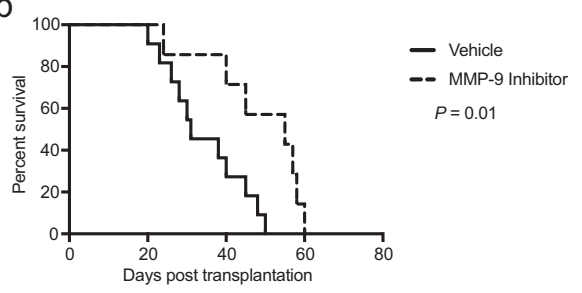

C
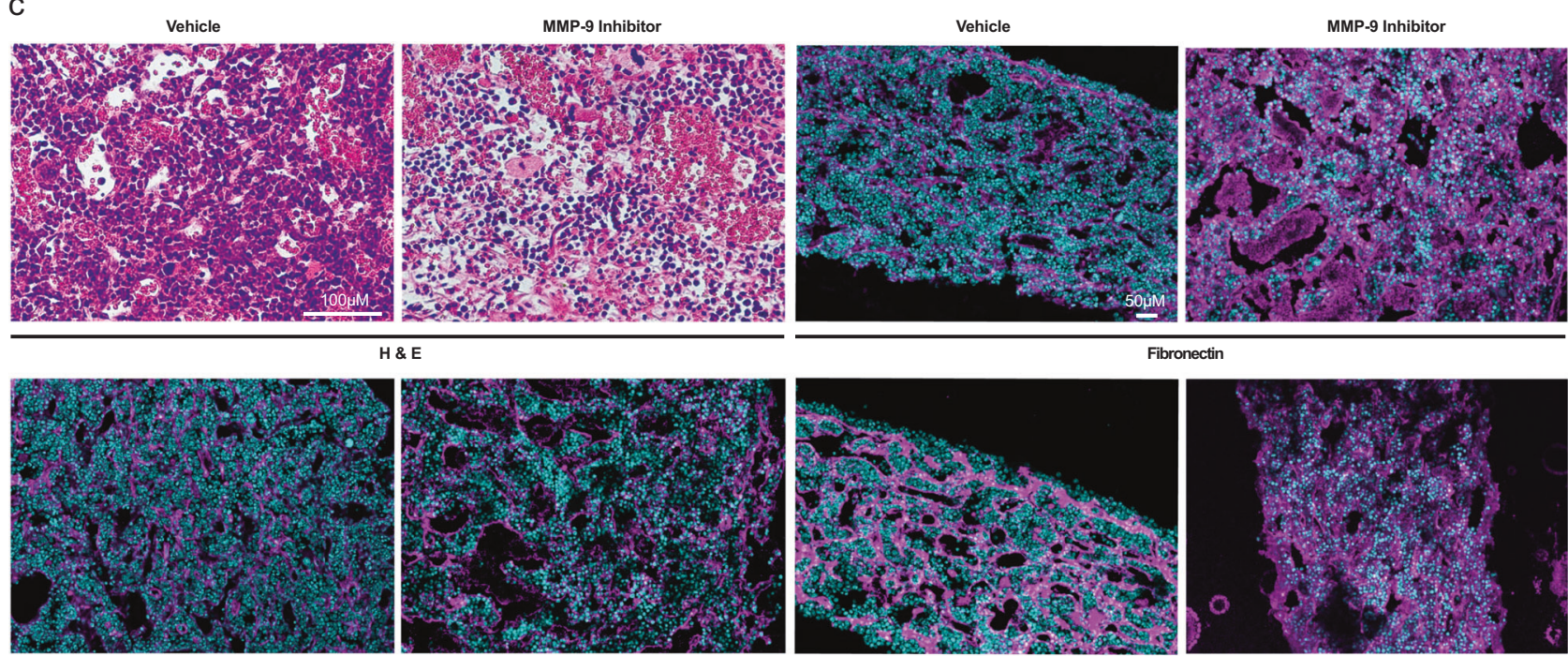

$H \& E$

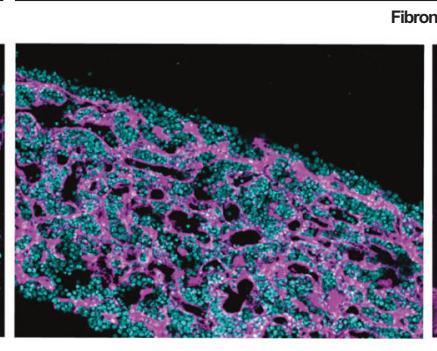

ronectin

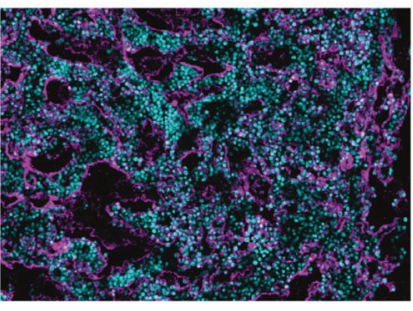

Laminin

Collagen

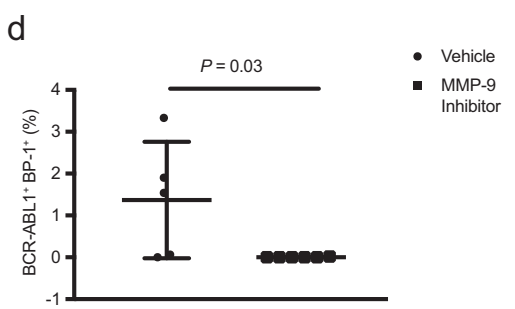

e

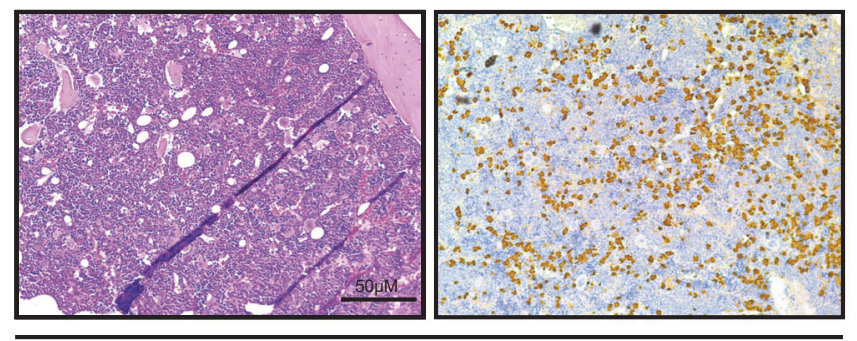

Ara-C

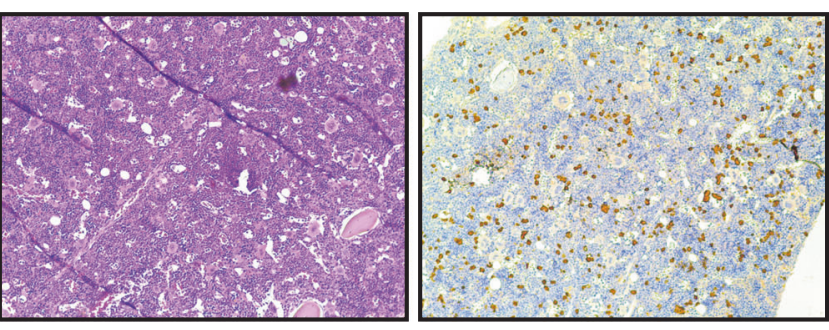

MMP9 Inhibitor + Ara-C

(Fig. S10E). In all examined tissues the combination treatment was not more effective than ara-C alone, which alone was so potent, that it effectively eradicated the disease and prevented death due to leukemia. However, testing minimal residual disease (MRD), which is responsible for disease relapse in patients with B-ALL, at the time of death a reduction of $\mathrm{GFP}^{+}\left(\mathrm{BCR}^{-\mathrm{ABL1}}{ }^{+}\right) \mathrm{MRD}$ was found in the
BM when mice with B-ALL had been treated with ara-C and the MMP-9 inhibitor compared with mice treated with ara-C alone $(P=0.003$, Figs. 6e and S10F). Disease burden was similar between treatment groups prior to the start of therapy (Fig. S10G). In summary, treatment of B-ALL mice with an MMP-9 inhibitor prolonged survival of mice with B-ALL, likely via reduction of the degradation of ECM 
Fig. 6 Treatment with an MMP-9-inhibitor prolongs survival in BALL. a Percentage of $\mathrm{GFP}^{+}\left(\mathrm{BCR}-\mathrm{ABL1}^{+}\right) \mathrm{BP}-1^{+}$cells in peripheral blood of vehicle (black circles)- or MMP-9 inhibitor (black squares)treated mice on day 25 of transplantation of BCR-ABL1-transduced bone marrow ( $P=0.04 ; t$ test, $n=7-11)$. b Kaplan-Meier-style survival curve of vehicle (solid line)- or MMP-9 inhibitor (dashed line)treated mice transplanted with $1 \times 10^{6} \mathrm{BCR}-\mathrm{ABL} 1$-transduced bone marrow cells $(P=0.01$, Log-rank test, $n=7-11)$. The mice were treated with the MMP-9 inhibitor 2-3 times per week at a dose of $20 \mathrm{mg} / \mathrm{kg}$ beginning at day 12 after transplantation. $\mathbf{c}$ Bone sections of mice with B-ALL treated with vehicle or the MMP-9 inhibitor stained with hematoxylin and eosin (H\&E) (top left) or antibodies to fibronectin (pink; top right), laminin (pink; bottom left), or collagen (pink; bottom right) in immunofluorescence studies. The dosing of the MMP9 inhibitor was as described in $\mathbf{b}$. The scale bar depicts $100 \mu \mathrm{m}$ in the slides stained with $\mathrm{H} \& \mathrm{E}$ and $50 \mu \mathrm{m}$ in the immunofluorescence studies. d Percentage of $\mathrm{GFP}^{+}\left(\mathrm{BCR}-\mathrm{ABL1}^{+}\right) \mathrm{BP}^{-} 1^{+}$lymphoid cells in peripheral blood of wild type, untreated secondary recipients of BCR$\mathrm{ABL}^{+}{ }^{+}$bone marrow from vehicle (black circles)- or MMP-9 inhibitor (black squares)-treated primary mice with B-ALL on day 18 after transplantation $(P=0.03 ; t$ test, $n=5)$. e Representative images of bone sections of mice with B-ALL treated with the chemotherapeutic agent cytarabine (top) (ara-C; $50 \mathrm{mg} / \mathrm{kg}$ from day 12 for 5 days, followed by 2 weeks rest) or the MMP-9 inhibitor $(20 \mathrm{mg} / \mathrm{kg})$ and cytarabine (bottom) stained with hematoxylin and eosin (H\&E) (left) or anti-GFP (detected by immunoperoxidase using yellow-brown horseradish-peroxidase chromogen; BCR-ABL1 ${ }^{+}$B-ALL cells; right) by immunohistochemistry. The scale bar depicts $50 \mu \mathrm{m}$.

proteins, without overt toxicity. However, at the chosen dose of ara-C, the tumor burden could not be further reduced or survival prolonged when ara- $\mathrm{C}$ was combined with an MMP-9-inhibitor. Our data suggest, that inhibition of MMP-9 may be a feasible adjunct to existing therapies of B-ALL, while also reducing MRD.

\section{Levels of fibronectin in bone sections of patients with B-ALL are reduced}

In human samples we revealed a decreased amount of fibronectin in bone sections of patients with B-ALL compared with healthy controls (Fig. 7a). Levels of fibronectin in bone sections of patients with B-ALL were also significantly reduced compared with bone sections of patients with CML (Fig. S11A). In contrast, the concentration of MMP-9 in the plasma of BM aspirates was highest in patients with CML versus healthy controls and patients with B-ALL (Fig. S11B). As revealed by the punctate staining pattern for MMP-9 by immunohistochemistry, however, these high levels of MMP-9 in healthy controls and CML patients were likely due to MMP-9 production by myeloid cells compared with a more diffuse staining pattern in BALL patients (Fig. S11C). These data suggest that the concept of decreased ECM proteins in a B-ALL BMM, possibly leading to increased invasion of B-ALL cells and leukemia progression, may also apply to the clinical setting. However, in healthy controls and CML patients MMP-9 is largely produced by myeloid cells.

\section{Discussion}

Here we report that BCR-ABL1 ${ }^{+}$B-ALL cells remodel the BM niche via the release of Tnfo, which activates the NF$\mathrm{kB}$ pathway downstream of TNFR1 leading to increased expression and release of MMP-9. Increased production of functional MMP-9 in the BMM degrades ECM proteins such as fibronectin, laminin, and collagen facilitating the migration/invasion of B-ALL cells in the BM, as well as in different organs in our murine model. Reduced infiltration of the BM and peripheral organs by leukemic cells decreases disease aggressiveness and, consequently, prolongs the survival of mice with B-ALL. Our results also demonstrate that inhibition of MMP-9 can be used therapeutically in our murine model of B-ALL without overt toxicity.

Most previous reports on the role of MMP-9 in cancer have focused on the cancer cell-specific production and release of MMP-9 leading to increased invasion [16, 31] and progression [32], both in solid tumors [33], as well as
Fig. 7 Fibronectin levels may be reduced in bone sections of patients with B-ALL.

Representative images of bone sections of a healthy individual (control; left) versus a patient with B-ALL (right) stained with an antibody to fibronectin (detected by immunoperoxidase using yellow-brown horseradishperoxidase chromogen) in immunohistochemistry studies. The scale bar depicts $100 \mu \mathrm{m}$.

\section{a}

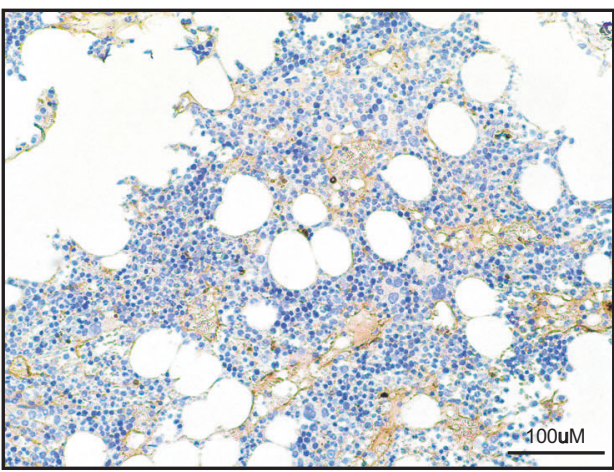

Control human bone marrow b

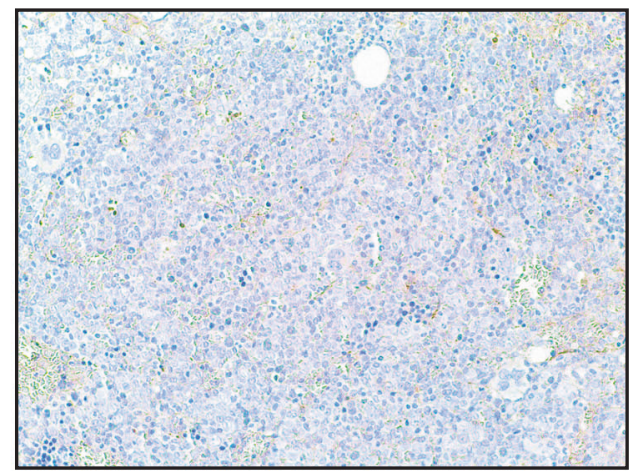

ALL human bone marrow 
in leukemia [23, 34]. MMP-9 production in solid tumors has also been associated with increased metastasis [35], and in B-cell CLL levels of MMP-9 in plasma correlate with prognosis [36]. In a large proportion of B-ALL cases, leukemia cell-specific production of MMP-9 has been shown [37], as also described in the BloodSPot Database and found to a low extent in our study. However, as demonstrated in our data, leukemia cell-specific production of MMP-9 does not influence survival (Fig. S1C), suggesting that the Tnfo-induced production of MMP-9 by MSC and possibly other niche cells plays a more prominent role. Production and release of pro-MMP-9, which is activated to functional MMP-9, has been shown to lead to degradation of ECM proteins enhancing cancer progression [38], similar to our study. However, the source of MMP-9 may also lie in the BMM, as our data show. Further, our findings are consistent with several other studies demonstrating the ability of leukemia cells to remodel the BMM into a leukemia-promoting and -perpetuating niche via the release of cytokines [2, 3, 39], extracellular vesicles [40] or other pathways [41]. Whether our observations are specific to $\mathrm{BCR}-\mathrm{ABL}^{+}{ }^{+}$leukemia will be assessed in future.

Several chronic inflammatory conditions such as inflammatory bowel disease or chronic infection by helicobacter pylori and others have been associated with cancer [42]. A role of Tnfo for these inflammation-associated cancers has been implicated, as mice deficient for Tnf $\alpha$ have reduced susceptibility for skin cancers [43]. In pancreatic cancer $\operatorname{Tnf} \alpha$ as a proinflammatory cytokine has been strongly associated with increased invasion, and inhibition of Tnf $\alpha$ led to antitumoral effects [44], while blockade of Tnfo reduced carcinogenesis in a model of chronic colitis [45]. In agreement with our study autocrine secretion of Tnf $\alpha$ has been shown to support and maintain leukemia cells in CML [46], and Tnfo treatment of leukemia cells is known to lead to NFkB-mediated transcription of MMP-9 [47]. However, the effect of Tnf $\alpha$ on remodeling of the BMM had not been investigated in the setting of CML.

In agreement with the studies by Schepers et al. in CML [48] or by Arranz et al. in myeloproliferative neoplasia [39], we demonstrate that leukemia cells produce inflammatory cytokines, with $\operatorname{Tn} f \alpha$ being one of the main mediators of niche remodeling in B-ALL. However, the involvement of other inflammatory cytokines released from B-ALL cells for the remodeling of the BMM cannot be excluded and needs to be addressed in future. While the knockdown of Tnfo in leukemia cells in our study prolonged the survival of mice with B-ALL by a concomitant reduction in MMP-9 production by the BMM (Fig. S8E), the impairment of autocrine, leukemia-promoting secretion of Tnfo, as shown in CML [46], may be contributory.
Relapse after first line therapies is a major drawback in various cancer treatments, which holds true in the case of BALL. MRD, including residual leukemia cells in the central nervous system [49], is known to be associated with relapse in B-ALL patients [50]. While toxic effects from inhibition of MMP-9 led to the failure of this treatment in various solid tumor therapies, we observed that B-ALL cellspossibly in conjunction with cytarabine-are highly sensitive to MMP-9 inhibition at lower doses, which led to reduced leukemia progression but no overt toxicity. MMP-9 inhibition also efficiently reduced MRD, including in the "sanctuary" of the central nervous system, i.e., the meninges. Therefore, careful exploration of the clinical benefit of MMP-9 inhibition at low dose or a therapeutic decrease of MMP-9 levels by other methods such as by RNA silencing therapeutics for reduction of MRD in B-ALL may be a worthwhile cause. Hereby, inhibition of cancer cell-intrinsic production and secretion of MMP-9, of course, cannot be ruled out.

The higher levels of fibronectin in the BMM and higher MMP-9 levels in the plasma of BM aspirates of healthy individuals and CML compared with B-ALL patients may seem contradictory, but may be explained by the increased production of MMP-9 by myeloid cells [18], the production of fibronectin by CML cells [51], or by other compensatory factors.

In summary, our data suggest that a proinflammatory state is created in the leukemic BMM in B-ALL by the release of Tnf $\alpha$, which leads to remodeling of the BMM, breakdown of the ECM, and increased invasion of leukemia cells via the secretion of MMP-9 from MSC. Therapeutic administration of an MMP-9 inhibitor at lower dose in conjunction with chemotherapeutic agents may counteract this pathway, decrease MRD and prolong survival in patients.

Acknowledgements This work was supported by the LOEWE Center for Cell and Gene Therapy Frankfurt (CGT) and institutional funds of the Georg-Speyer-Haus to DSK. The Georg-Speyer-Haus is funded jointly by the German Federal Ministry of Health (BMG) and the Ministry of Higher Education, Research and the Arts of the State of Hessen (HMWK). The LOEWE Center for Cell and Gene Therapy Frankfurt is funded by HMWK, reference number: III L 4-518/17.004 (2010).

Author contributions DV designed and carried out experiments, analyzed the data, and wrote a first draft of the paper. CZ designed and carried out experiments, analyzed the data, and performed immunofluorescence studies. PSG carried out experiments, analyzed the data, and provided assistance with the CHIP assay. RK provided assistance with transplantation experiments, the zymography, and participated in discussions and reviewed the paper. VRM performed zymography studies and MSC-related experiments. VM-S, SL, FEN, and $\mathrm{MM}$ provided plasma from human $\mathrm{BM}$ aspirates. $\mathrm{BB}$ and $\mathrm{MF}$ provided bone sections from human patients. DSK designed experiments, analyzed data, supervised the project, and wrote the paper. 


\section{Compliance with ethical standards}

Conflict of interest The authors declare that they have no conflict of interest.

Publisher's note Springer Nature remains neutral with regard to jurisdictional claims in published maps and institutional affiliations.

Open Access This article is licensed under a Creative Commons Attribution 4.0 International License, which permits use, sharing, adaptation, distribution and reproduction in any medium or format, as long as you give appropriate credit to the original author(s) and the source, provide a link to the Creative Commons license, and indicate if changes were made. The images or other third party material in this article are included in the article's Creative Commons license, unless indicated otherwise in a credit line to the material. If material is not included in the article's Creative Commons license and your intended use is not permitted by statutory regulation or exceeds the permitted use, you will need to obtain permission directly from the copyright holder. To view a copy of this license, visit http://creativecommons. org/licenses/by/4.0/.

\section{References}

1. Krause DS, Fulzele K, Catic A, Sun CC, Dombkowski D, Hurley $\mathrm{MP}$, et al. Differential regulation of myeloid leukemias by the bone marrow microenvironment. Nat Med. 2013;19:1513-7.

2. Schepers K, Pietras EM, Reynaud D, Flach J, Binnewies M, Garg $\mathrm{T}$, et al. Myeloproliferative neoplasia remodels the endosteal bone marrow niche into a self-reinforcing leukemic niche. Cell Stem Cell. 2013;13:285-99.

3. Frisch BJ, Ashton JM, Xing L, Becker MW, Jordan CT, Calvi LM. Functional inhibition of osteoblastic cells in an in vivo mouse model of myeloid leukemia. Blood. 2012;119:540-50.

4. Zhang B, Li M, McDonald T, Holyoake TL, Moon RT, Campana $\mathrm{D}$, et al. Microenvironmental protection of CML stem and progenitor cells from tyrosine kinase inhibitors through $\mathrm{N}$-cadherin and Wnt-beta-catenin signaling. Blood. 2013;121:1824-38.

5. Boyerinas B, Zafrir M, Yesilkanal AE, Price TT, Hyjek EM, Sipkins DA. Adhesion to osteopontin in the bone marrow niche regulates lymphoblastic leukemia cell dormancy. Blood. 2013; 121:4821-31.

6. Hsieh YT, Gang EJ, Geng H, Park E, Huantes S, Chudziak D, et al. Integrin alpha4 blockade sensitizes drug resistant pre-B acute lymphoblastic leukemia to chemotherapy. Blood. 2013;121:1814-8.

7. Klein G. The extracellular matrix of the hematopoietic microenvironment. Experientia. 1995;51:914-26.

8. Nakamura-Ishizu A, Okuno Y, Omatsu Y, Okabe K, Morimoto J, Uede $\mathrm{T}$, et al. Extracellular matrix protein tenascin- $\mathrm{C}$ is required in the bone marrow microenvironment primed for hematopoietic regeneration. Blood. 2012;119:5429-37.

9. Stier S, Ko Y, Forkert R, Lutz C, Neuhaus T, Grunewad E, et al. Osteopontin is a hematopoietic stem cell niche component that negatively regulates stem cell pool size. J Exp Med. 2005;201: 1781.

10. Probst K, Stermann J, von Bomhard I, Etich J, Pitzler L, Niehoff A, et al. Depletion of collagen IX Alpha1 impairs myeloid cell function. Stem Cells. 2018;36:1752-63.

11. Mitroulis I, Chen LS, Singh RP, Kourtzelis I, Economopoulou M, Kajikawa T, et al. Secreted protein Del-1 regulates myelopoiesis in the hematopoietic stem cell niche. J Clin Investig. 2017;127: 3624-39.

12. Ma Z, Zhao X, Deng M, Huang Z, Wang J, Wu Y, et al. Bone marrow mesenchymal stromal cell-derived periostin promotes B-
ALL progression by modulating CCL2 in leukemia cells. Cell Rep. 2019;26:1533-43.

13. Christopherson KW, Cooper S, Hangoc G, Broxmeyer HE. CD26 is essential for normal G-CSF-induced progenitor cell mobilization as determined by CD26- $/-$ mice. Exp Hematol. 2003;31:1126-34.

14. Klein G, Schmal O, Aicher WK. Matrix metalloproteinases in stem cell mobilization. Matrix Biol. 2015;44-46: 175-83.

15. Spiegel A, Zcharia E, Vagima Y, Itkin T, Kalinkovich A, Dar A, et al. Heparanase regulates retention and proliferation of primitive Sca-1+/c-Kit+/Lin- cells via modulation of the bone marrow microenvironment. Blood. 2008;111:4934-43.

16. Mehner C, Hockla A, Miller E, Ran S, Radisky DC, Radisky ES. Tumor cell-produced matrix metalloproteinase 9 (MMP-9) drives malignant progression and metastasis of basal-like triple negative breast cancer. Oncotarget. 2014;5:2736-49.

17. Reggiani F, Labanca V, Mancuso P, Rabascio C, Talarico G, Orecchioni S, et al. Adipose progenitor cell secretion of GM-CSF and MMP9 promotes a stromal and immunological microenvironment that supports breast cancer progression. Cancer Res. 2017;77:5169-82.

18. Coussens LM, Tinkle CL, Hanahan D, Werb Z. MMP-9 supplied by bone marrow-derived cells contributes to skin carcinogenesis. Cell. 2000;103:481-90.

19. Iwata M, Pillai M, Ramakrishnan A, Hackman RC, Deeg HJ, Opdenakker G, et al. Reduced expression of inducible gelatinase $\mathrm{B} /$ matrix metalloproteinase-9 in monocytes from patients with myelodysplastic syndrome: correlation of inducible levels with the percentage of cytogenetically marked cells and with marrow cellularity. Blood. 2007;109:85-92.

20. Ries C, Egea V, Karow M, Kolb H, Jochum M, Neth P. MMP-2, MT1-MMP, and TIMP-2 are essential for the invasive capacity of human mesenchymal stem cells: differential regulation by inflammatory cytokines. Blood. 2007;109:4055-63.

21. Shi Y, Du L, Lin L, Wang Y. Tumour-associated mesenchymal stem/stromal cells: emerging therapeutic targets. Nat Rev Drug Discov. 2017;16:35-52.

22. Mu M, Song Y, Zhang B. Expression and survival significance of B-cell-specific Moloney murine leukemia virus integration site 1 and matrix metalloproteinase-9 in non-small-cell lung cancer. Oncol Lett. 2016;12:3715-22.

23. Redondo-Muñoz J, Ugarte-Berzal E, Terol MJ, Van den Steen PE, Hernández del Cerro $M$, Roderfeld $M$, et al. Matrix metalloproteinase-9 promotes chronic lymphocytic leukemia $b$ cell survival through its hemopexin domain. Cancer Cell. 2010;17:160-72.

24. Song J, Zhang X, Buscher K, Wang Y, Wang H, Di Russo J, et al. Endothelial basement membrane laminin 511 contributes to endothelial junctional tightness and thereby inhibits leukocyte transmigration. Cell Rep. 2017;18:1256-69.

25. Verma D, Kumar R, Pereira R, Karantanou C, Zanetti C, Minciacchi VR, et al. Vitamin K-antagonism impairs the bone marrow microenvironment and hematopoiesis. Blood. 2019;134:227-38.

26. Chang MK, Raggatt LJ, Alexander KA, Kuliwaba JS, Fazzalari NL, Schroder K, et al. Osteal tissue macrophages are intercalated throughout human and mouse bone lining tissues and regulate osteoblast function in vitro and in vivo. $\mathrm{J}$ Immunol. 2008;181:1232-44.

27. Davis V, Persidskaia R, Baca-Regen L, Itoh Y, Nagase H, Persidsky $\mathrm{Y}$, et al. Matrix metalloproteinase-2 production and its binding to the matrix are increased in abdominal aortic aneurysms. Arterioscler Thromb Vasc Biol. 1998;18:1652-33.

28. Yan L, Zheng D, Xu RH. Critical role of tumor necrosis factor signaling in mesenchymal stem cell-based therapy for autoimmune and inflammatory diseases. Front Immunol. 2018; 20:1658. 
29. Li CW, Xia W, Huo L, Lim SO, Wu Y, Hsu JL, et al. Epithelialmesenchymal transition induced by $T n f-\alpha$ requires NF- $\mathrm{KB}-$ mediated transcriptional upregulation of Twist1. Cancer Res. 2012;72:1290-1300.

30. Schütze S, Wiegmann K, Machleidt T, TNF-induced MK. activation of NF-kappa B. Immunobiology. 1995;193:193-203.

31. Cheng X, Yang Y, Fan Z, Yu L, Bai H, Zhou B, et al. MKL1 potentiates lung cancer cell migration and invasion by epigenetically activating MMP9 transcription. Oncogene. 2015;34:5570-81.

32. Bergers G, Brekken R, McMahon G, Vu TH, Itoh T, Tamaki K, et al. Matrix metalloproteinase-9 triggers the angiogenic switch during carcinogenesis. Nat Cell Biol. 2000;2:737-44.

33. Schmalfeldt B, Prechtel D, Härting K, Späthe K, Rutke S, Konik $\mathrm{E}$, et al. Increased expression of matrix metalloproteinases (MMP)-2, MMP-9, and the urokinase-type plasminogen activator is associated with progression from benign to advanced ovarian cancer. Clin Cancer Res. 2001;7:2396-404.

34. Redondo-Muñoz J, Escobar-Díaz E, Samaniego R, Terol MJ, García-Marco JA, García-Pardo A. MMP-9 in B-cell chronic lymphocytic leukemia is up-regulated by alpha4beta1 integrin or CXCR4 engagement via distinct signaling pathways, localizes to podosomes, and is involved in cell invasion and migration. Blood. 2006;108:3143-51.

35. Hiratsuka S, Nakamura K, Iwai S, Murakami M, Itoh T, Kijima H, et al. MMP9 induction by vascular endothelial growth factor receptor-1 is involved in lung-specific metastasis. Cancer Cell. 2002;2:289-300.

36. Gusella M, Bolzonella C, Paolini R, Rodella E, Bertolaso L, Scipioni C. et al. Plasma matrix metalloprotease 9 correlates with blood lymphocytosis, leukemic cell invasiveness, and prognosis in B-cell chronic lymphocytic leukemia. Tumour Biol. 2017;39: 1010428317694325.

37. Pegahi R, Poyer F, Legrand E, Cazin L, Vannier JP, Lamacz M. Spontaneous and cytokine-evoked production of matrix metalloproteinases by bone marrow and peripheral blood pre-B cells in childhood acute lymphoblastic leukaemia. Eur Cytokine Netw. 2005;16:223-32.

38. Kessenbrock K, Plaks V, Werb Z. Matrix metalloproteinases: regulators of the tumor microenvironment. Cell. 2010;141:52-67.

39. Arranz L, Sanchez-Aguilera A, Martin-Perez D, Isern J, Langa X, Tzankov A, et al. Neuropathy of haematopoietic stem cell niche is essential for myeloproliferative neoplasms. Nature. 2014. https:// doi.org/10.1038/nature13383.

40. Kumar B, Garcia M, Weng L, Jung X, Murakami JL, Hu X, et al. Acute myeloid leukemia transforms the bone marrow niche into a leukemia-permissive microenvironment through exosome secretion. Leukemia. 2018;32:575-87.

41. de Rooij B, Polak R, Stalpers F, Pieters R, Boer MLd. Tunneling nanotubes facilitate autophagosome transfer in the leukemic niche. Leukemia. 2017;31:1651-4.

42. Thun MJ, Henley SJ, Gansler T. Inflammation and cancer: an epidemiological perspective. Novartis Found Symp. 2004;256:6-21.

43. Moore RJ, Owens DM, Stamp G, Arnott C, Burke F, East N, et al. Mice deficient in tumor necrosis factor-alpha are resistant to skin carcinogenesis. Nat Med. 1999;5:828-31.

44. Egberts JH, Cloosters V, Noack A, Schniewind B, Thon L, Klose S, et al. Anti-tumor necrosis factor therapy inhibits pancreatic tumor growth and metastasis. Cancer Res. 2008;68: 1443-50.

45. Popivanova BK, Kitamura K, Wu Y, Kondo T, Kagaya T, Kaneko $\mathrm{S}$, et al. Blocking TNF-alpha in mice reduces colorectal carcinogenesis associated with chronic colitis. J Clin Investig. 2008;118: 560-70.

46. Gallipoli P, Pellicano F, Morrison H, Laidlaw K, Allan EK, Bhatia $\mathrm{R}$, et al. Autocrine TNF- $\alpha$ production supports CML stem and progenitor cell survival and enhances their proliferation. Blood. 2013;122:3335-9.

47. Chen YJ, Chang LS. NFкB- and AP-1-mediated DNA looping regulates matrix metalloproteinase- 9 transcription in TNF- $\alpha$ treated human leukemia U937 cells. Biochim Biophys Acta. 2015; 1849:1248-59.

48. Schepers K, Campbell Timothy B, Passegué E. Normal and leukemic stem cell niches: insights and therapeutic opportunities. Cell Stem Cell. 2015;16:254-67.

49. Winick N, Devidas M, Chen S, Maloney K, Larsen E, Mattano L, et al. Impact of initial CSF findings on outcome among patients with National Cancer Institute standard- and high-risk B-cell acute lymphoblastic leukemia: a report from the children's oncology group. J Clin Oncol. 2017;35:2527-34.

50. Jourdain A, Auperin A, Minard-Colin V, Aladjidi N, Zsiros J, Coze $\mathrm{C}$, et al. Outcome of and prognostic factors for relapse in children and adolescents with mature B-cell lymphoma and leukemia treated in three consecutive prospective "Lymphomes Malins B" protocols. A Société Française des Cancers de l'Enfant study. Haematologica. 2015;100:810-7.

51. Kumar R, Merten M, Minciacchi V, Pereira R, Zanetti C, Hayduk N, et al. Specific and targetable interactions with the bone marrow microenvironment govern outcome in imatinibresistant chronic myeloid leukemia. Blood. 2018; ASH abstract \#936. 